\title{
Donald A. Pious
}

1930-1998

\author{
Mike Bevan \\ Department of Immunology, University of Washington, Seattle, Wash., USA
}

Donald A. Pious, who laid the groundwork for a somatic cell genetic analysis of human immune response genes, died of cancer on September 6, 1998, at his home in Seattle. He was 68 and a Professor in the Departments of Pediatrics, Immunology, and Genetics at the University of Washington.

Dr. Pious was one of the first scientists to apply the powerful tool of mutant selection, first established in studies of bacteria, to cultured human cells. He and his colleagues were the first to produce mutations of key immune system genes in cultured human cell lines. This breakthrough made it possible to compare the ability of normal versus modified white blood cells to initiate immune responses to infection and led to the discovery of new genes that control those responses. The cell lines were disseminated for study throughout the world, and many important insights into how immune responses are initiated were achieved by Dr. Pious' group and others. The molecules he focused on are those controlled by the major histocompatibility complex, which are implicated in the recognition of infectious agents, help protect the body from disease and are important for successful organ transplantation. Central to the immune response, such as antibody formation, is the way in which an antigen is processed and present- ed to the immune system. Some of the mutations the Pious group produced revealed new and previously unsuspected steps in this process of antigen presentation.

Dr. Pious received both his B.S. (1952) and his M.D. (1956) degrees from the University of Pennsylvania and was trained in Pediatrics at Yale University (1957-1959). He joined the faculty of the University of Washington in 1964 and advanced to full Professor in 1976. He was instrumental in creating the Department of Immunology at the University of Washington in 1989 and had recently been recognized by the Department of Pediatrics with a laboratory named in his honor. Don Pious will be missed by his colleagues for his exceptional grace and style. He was a true gentleman of science, modest and generous.

Dr. Pious was an avid hiker and traveler who shared with everyone his immense curiosity and wonderment about the places he visited. Jazz was another of his great loves, and he brought style, wit and enthusiasm to his tenor sax playing with the Madrona Jazz Trio. He is survived by his wife Constance of Seattle, Wash., his son Anthony of Oakland, Calif., his daughter Lisa Pious and her husband, Stefan Milnor, of Berkeley, Calif., and his sister Barbara Bresler of Fairfield, Conn.

\begin{tabular}{ll}
\hline KARGER & $\oplus 1999$ S. Karger AG, Basel \\
Fax +41 61 306 1234 & \\
$\begin{array}{l}\text { E-Mail karger@karger.ch } \\
\text { www.karger.com }\end{array}$ & $\begin{array}{l}\text { Accessible online at: } \\
\text { http://BioMedNet.com/karger }\end{array}$
\end{tabular}

